\title{
Association between genetic polymorphism of XRCC6 T-991C and risk of varicocele
}

\author{
Mohammad Reza Namvaran ${ }^{1}$, Zahra Beyzaei ${ }^{2^{*}}$ (D, Mohammad Javad Mokhtari ${ }^{1}$ and Bita Geramizadeh ${ }^{2,3}$
}

\begin{abstract}
Background: The DNA non-homologous end-joining repair gene XRCC6 (Ku70) plays an essential role in the DNA double-strand break (DSB) repairs. Defects in the DSB repair pathway results in genomic instability. Varicocele is characterized by high pressure and stasis in the veins of the testis. There is little knowledge about the molecular mechanisms underlying varicocele. One of the reasons for increased spermatozoa DNA damage is high concentrations of reactive oxygen species (ROS), which leads to DNA-DSBs. We assumed that a promoter T-991C (rs5751129) polymorphism in the XRCC6 gene was associated with susceptibility to varicocele in infertile men. Therefore, 63 infertile varicocele men and 150 healthy controls were recruited in our study. The healthy controls had no history of varicocele, and they were matched with patients by age.

Results: Our results showed that infertile varicocele patients and control groups had significant differences in the distribution of their genotypic and allelic frequency $(p=0.00)$ in the XRCC6 promoter T-991C polymorphism. Men who carried CC genotype had a 5.22-fold increased odds ratio of developing infertile varicocele compared to those who carried the wild-type $\Pi$ genotype (95\% Cl 2.31-11.81, $P<0.001)$.

Conclusions: Our results suggested that the CC genotype and the $C$ allele in the promoter region of XRCC6 gene might play an important role in developing infertility in the varicocele men. Further research is needed to provide the effect of this polymorphism.
\end{abstract}

Keywords: X-ray repair cross-complementing group 6 gene (XRCC6), Varicocele, Polymorphism, DNA repair, Nonhomologous end-joining, Genotype

\section{Background}

Varicocele is characterized by high pressure and stasis in the veins of the testis; it organizes the pampiniform vein plexus in the male spermatic cord [1]. It is mostly detected in young adults, which can harmfully affect the testicular function. The molecular mechanism underlying the pathogenesis of varicocele has not been elucidated yet.

The common feature of infertile varicocele patients is the increase in the sperm nuclear DNA fragments [2]. Saleh et al. [3] reported that sperm DNA damage in the infertile varicocele patients is significantly increased. The

\footnotetext{
* Correspondence: Z.beyzaei@gmail.com; z.beyzaei@gmail.com

${ }^{2}$ Transplant Research Center, Shiraz University of Medical Sciences, Khalili St., Research Center Tower, Seventh Floor, Shiraz Transplant Research Center (STRC), Shiraz, Iran

Full list of author information is available at the end of the article
}

reasons for increased sperm DNA damage in infertile varicocele patients are high concentrations of reactive oxygen species (ROS) as well as a reduction in antioxidant defenses [4]. Many reports documented the relationship between the polymorphism of DNA repair genes and the amount of ROS production, which leads to the risk of male infertility diseases [5-8].

One of the most harmful effects of ROS on DNA is double-strand breaks (DSBs) which affect the loss of physical integrity and content of DNA [9]. The homologous recombination (HR) and non-homologous endjoining (NHEJ) are two main DBS repair sub-pathways. Some studies have indicated that single nucleotide polymorphisms (SNPs) in NHEJ genes might cause suboptimal DNA repair and, as a result, accumulation of DNA damage. The most important component of NHEJ 
pathway is XRCC6 gene. It codes the Ku70 protein, a catalytic subunit of the NHEJ pathway, and plays an essential role in the maintenance of genome integrity [10]. A number of studies have evaluated the contribution of XRCC6 gene polymorphism and cancers; however, no study has yet confirmed the association between the polymorphisms of XRCC6 and the risk of varicocele [9-13]. Therefore, in this study, we assumed that polymorphisms of the gene in NHEJ pathway, like XRCC6, might also contribute to varicocele susceptibility. To test this hypothesis, we determined the genotypic frequency of polymorphism of the XRCC6 gene at the promoter T-991C (rs5751129), the region in this case-control study.

\section{Methods}

\section{Study population}

A total of sixty-three infertile patients with varicocele were recruited from the Nemazi Hospital between 2017 and 2019 from the Fars province, south of Iran. The clinician approved the diagnosis of varicocele with infertility in all patients. All the married patients were adult infertile men with a primary diagnosis of unilateral or bilateral varicocele. All cases had grades 2 and 3 varicocele without other diseases that lead to infertility, e.g., sexually transmitted diseases (STDs) and diabetes. They had an infertility problem from 1.5 to 5.8 years. Patients lacking a defined grade or grade 1 were excluded.

Age-matched healthy married men with children (150 men) from the same place were collected. They were without varicocele and no infertility problem. The controls with a history of varicocele and/or known causes of infertility such as hormone abnormalities, cryptorchidism, infection problems, orchitis, obstruction of the vas deferens, drug abuse, diabetes mellitus, and abnormal karyotypes were excluded. All our patients and controls were chosen from Caucasian Persian Muslim people living in the Fars province. Both the patient and control group filled out the questionnaire and provided written informed consent to participate in the study. This study was conducted in accordance with the guidelines of the Declaration of Helsinki and its subsequent amendments.

\section{Genotyping method}

Genomic DNA was extracted from EDTA-whole blood samples, from patients and healthy controls, using a Genomic DNA miniprep kit (Bio Basic, Canada). The extracted DNA was stored at $-20{ }^{\circ} \mathrm{C}$ until the performance of PCR analysis. RFLP-PCR and designing of the primers were performed, as described previously [11]. Briefly, PCR conditions were 1 cycle at $94{ }^{\circ} \mathrm{C}$ for $5 \mathrm{~min}$, 29 cycles of $94{ }^{\circ} \mathrm{C}$ for $30 \mathrm{~s}, 55.5^{\circ} \mathrm{C}$ for $40 \mathrm{~s}, 72{ }^{\circ} \mathrm{C}$ for 45 $\mathrm{s}$, and $72{ }^{\circ} \mathrm{C}$ for $10 \mathrm{~min}$ as a final extension step. Then, 5 $\mu \mathrm{l}$ of XRCC6 T-991C products was mixed with $2 \mathrm{U}$ of DpnII. Then, the mixture was incubated for $2 \mathrm{~h}$ at $37^{\circ} \mathrm{C}$.
The wild-type C allele polymorphism had no DpnII cleavage site, with $301 \mathrm{bp}$ size, whereas the mutant $\mathrm{T}$ allele was digested to 200 and $101 \mathrm{bp}$ fragment size. The polymorphism was categorized as either $\mathrm{T} / \mathrm{T}$ homozygote (undigested), $\mathrm{C} / \mathrm{C}$ homozygote (digested), or $\mathrm{C} / \mathrm{T}$ heterozygote. PCR and/or digestion products were electrophoresed on a $2.5 \%$ agarose gel containing ethidium bromide.

\section{Statistical analyses}

Hardy-Weinberg equilibrium was calculated for both patients and control groups. Pearson's chi-square or Fisher's exact test was used to analyze the test differences in the frequency of alleles and genotypes. The association between XRCC6 polymorphism and varicocele risk was obtained by the odds ratios (OR) and $95 \%$ confidence intervals (CIs). All statistical analyses were done using SPSS software (version 16) for Windows (SPSS Inc., Chicago, IL, USA). $P<0.05$ was considered as significant, which was two-sided for all tests.

\section{Results}

The demographic characteristics of infertile varicocele patients and controls were studied. The average age of the patients was $32.4 \pm 2.3$ years, and the average age of the control group was $31.9 \pm 1.4$ years. The difference was not statistically significant $(P=0.58)$, which indicated that the two groups of patients were equal in age. Hence, in terms of body mass index, there was no difference between the two groups $(P=0.51)$.

The genotype distribution of the XRCC6 T-991C (rs5751129) gene polymorphism in sixty-three patients and one hundred fifty healthy men are presented in Table 1. The genotype frequency of XRCC6 polymorphism in infertile patients $\left(X^{2}=2.17, \mathrm{df}=1, P=0.14\right)$ and controls $\left(X^{2}=1.69, \mathrm{df}=1, P=0.20\right)$ was in HardyWeinberg equilibrium. SNP analysis of XRCC6 (rs5751129) polymorphism showed that the wild TT genotype was present in $14 / 63$ patients (22.20\%), while the variant genotypes $\mathrm{TC}$ and $\mathrm{CC}$ were present in $25 / 63$ patients (39.7\%) and $24 / 63$ patients (38.1\%), respectively. The genotype TC $(\mathrm{OR}=1.96,95 \%$ CI $0.93-4.11, P=$ 0.075 ) had no significant effect on the risk of varicocele in comparison with TT. The mutant homozygotes (CC) in patients had a significant 5.22-times higher risk than the controls $(95 \% \mathrm{CI} 2.31-11.81, P<0.001)$ in comparison with TT (Table 1). In addition, the combined $\mathrm{C}$ allele carrier $(\mathrm{TC}+\mathrm{CC})$ of infertile varicocele patients was 2.82-times higher than that of the control group, and there was a significant difference between the two groups (95\% CI 1.44-5.55, $P=0.003$ ). The frequency of allele $C$ in the varicocele group was significantly higher than the control group, and the difference was statistically significant $(95 \%$ CI $1.22-3.46, P<0.001)$ (Table 1$)$. 
Table 1 Association between polymorphism of XRCC6 T-991C and risk of varicocele

\begin{tabular}{|c|c|c|c|c|}
\hline \multirow[t]{2}{*}{ XRCC 6 polymorphism } & \multirow{2}{*}{$\begin{array}{l}\text { Cases }(n=63) \\
N(\%)\end{array}$} & Controls $(n=150)$ & \multirow[t]{2}{*}{ OR $(95 \% \mathrm{Cl})$} & \multirow[t]{2}{*}{$P$ value } \\
\hline & & $N(\%)$ & & \\
\hline TT & $14(22.2)$ & $67(45.0)$ & 1 & \\
\hline TC & $25(39.7)$ & $61(41.0)$ & $1.96(0.93-4.11)$ & 0.075 \\
\hline CC & $24(38.1)$ & $22(14.0)$ & $5.22(2.31-11.81)$ & $<0.001$ \\
\hline$\pi$ & $14(22)$ & $67(45)$ & 1 & \\
\hline $\mathrm{TC}+\mathrm{CC}$ & $49(78)$ & $83(55)$ & $2.82(1.44-5.55)$ & 0.003 \\
\hline $\mathrm{T}$ & $53(42.1)$ & $195(65)$ & 1 & \\
\hline C & $73(57.9)$ & $105(35)$ & $2.98(1.22-3.46)$ & $<0.001$ \\
\hline
\end{tabular}

\section{Discussion}

In this study, the association between the XRCC6 gene polymorphism and the risk of varicocele in the Iranian population was investigated. The genotyping analyses revealed that individuals who carried the $\mathrm{CC}$ genotype had a higher risk of varicocele compared with those carrying the TT genotype of XRCC6 T-991C. Previous reports have shown that there is a correlation between varicocele and body mass index, which has been observed to be more common in tall and fat men [14, 15]. However, in terms of body mass index, we did not find any correlation in all groups. To the best of our knowledge, this is the first report to investigate the susceptibility of the XRCC6 T-991C polymorphism in infertile varicocele men.

It is known that the NHEJ pathway plays a principal mechanism for the removal of DNA DSBs damages. It has a main role in genetic stability and maintenance of normal spermatogenesis. In this pathway, XRCC6 plays an important role, which may work with/without XRCC5 as a heterodimer [10].

The results of our study showed that carriers of the CC genotype and the $\mathrm{C}$ allele of XRCC6 were associated with a significantly increased risk of infertile men with varicocele. Our result may indicate that the mutant allele C of XRCC6 T-991C in the promoter region is considered to be as a risk factor for varicocele susceptibility with infertility.

The XRCC6 T-991C polymorphism, rs5751129, is located in the promoter region. It might influence the transcriptional activity of the gene [12, 16-18]. The genetic susceptibility of this polymorphism has been studied in a variety of diseases, including renal cell carcinoma [10], hepatocellular carcinoma [11], lung cancer [13], and male infertile patients [9]. Besides, previous results indicate that this SNP may affect the stability of Ku70 protein and its protein expression level, which may lead to alterations in DSB repair capacity $[19,20]$.

Therefore, the deficiency in XRCC6 may lead to not only a lower DSB repair capacity, but also hypersensitivity to ionizing radiation, growth retardation, and severe combined immune deficiency [21]. On the other hand, XRCC6 polymorphisms or small genomic variations might escape the cell cycle checkpoints and reduce DNA repair capacity, which might increase the fragmentation of sperm DNA in nuclear and trigger infertile varicocele patients [22, 23]. Therefore, the screening for specific DNA polymorphisms may have an application in infertile men in order to guide a targeted antioxidant treatment. It might bring a new insight into the management of men with infertility, especially infertile men with varicocele.

The present study had some limitations, which are suggested to be improved in future investigations. First, our population size was moderate, which may restrict the reliability and feasibility of analysis. Second, the lack of insufficient clinical and behavioral information, such as occupational exposure, smoking, and physical exercise habits limited our ability to analyze risk factors.

\section{Conclusions}

In summary, the present study is the first report to investigate the association between XRCC6 promoter T991C polymorphism and varicocele. Our findings suggest that the $\mathrm{CC}$ genotype is significantly associated with a higher susceptibility to varicocele. However, it is a preliminary study, so further large cohort studies adjusted for risk factors in varicocele and functional analysis are recommended to confirm the finding of our study.

\footnotetext{
Abbreviations

DSBs: Double-strand break; HR: Homologous recombination; NHEJ: Nonhomologous end joining; RFLP: Restriction fragment length polymorphism; ROS: Reactive oxygen species; XRCC6: X-ray repair cross-complementing group 6

Acknowledgements

The authors thank all participants in this study.

Authors' contributions

M.R.N., M.J.M., B.G., and Z.B. conceived and planned the presented experiment. M.R.N. and Z.B. performed the experiments and analyzed the data. Z.B. supervised the research, designed experiments, and wrote the paper. The authors have read and approved the manuscript.
} 
Funding

Not applicable

\section{Availability of data and materials}

Not applicable

\section{Ethics approval and consent to participate}

Parents of patients or legal guardians provided a written informed consent form for participation in the study. The Institutional Review Board and Human Ethics Committee of the Islamic Azad University of Kazerun approved this study (IR.IAU.KAU.REC.1398.189).

\section{Consent for publication}

Not applicable

\section{Competing interests}

Not applicable

\section{Author details}

'Department of Biology, Zarghan Branch, IAU, Zarghan, Iran. ${ }^{2}$ Transplant Research Center, Shiraz University of Medical Sciences, Khalili St., Research Center Tower, Seventh Floor, Shiraz Transplant Research Center (STRC),

Shiraz, Iran. ${ }^{3}$ Department of Pathology, Shiraz University of Medical Sciences, Shiraz, Iran.

Received: 1 October 2020 Accepted: 27 November 2020

Published online: 06 December 2020

\section{References}

1. Mohammed A, Chinegwundoh F (2009) Testicular varicocele: an overview. Urol Int 82:373-379

2. Meacham RB, Townsend RR, Rademacher D, Drose JA (1994) The incidence of varicoceles in the general population when evaluated by physical examination, gray scale sonography and color Doppler sonography. J Urol. 151:1535-1538

3. Saleh RA, Agarwal A, Sharma RK, Said TM, Sikka SC, Thoma AJ (2003) Evaluation of nuclear DNA damage in spermatozoa from infertile men with varicocele. Fertil Steril. 80:1431-1436

4. Talebi AR, Moein MR, Tabibnejad N, Ghasemzadeh J (2008) Effect of varicocele on chromatin condensation and DNA integrity of ejaculated spermatozoa using cytochemical tests. Andrologia. 40:245-251

5. Koksal IT, Tefekli A, Usta M, Erol H, Abbasoglu S, Kadioglu A (2000) The role of reactive oxygen species in testicular dysfunction associated with varicocele. BJU Int. 86:549-552

6. Sikka SC (1996) Oxidative stress and role of antioxidants in normal and abnormal sperm function. Front Biosci. 1:e78-e86

7. Kodama H, Yamaguchi R, Fukuda J, Kasai H, Tanaka T (1997) Increased oxidative deoxyribonucleic acid damage in the spermatozoa of infertile male patients. Fertil Steril. 68:519-524

8. Averina NG, Beyzaei Z, Sherbakov RV, Usatov AA (2014) Role of nitrogen metabolism in the development of salt tolerance in barley plants, Russian. J plant physiol. 61:97-104

9. Jahantigh D, Hosseinzadeh CA (2017) XRCC5 VNTR, XRCC6-61C>G, and XRCC7 6721G>T gene polymorphisms associated with male infertility risk: evidences from case-control and in silico studies. Int J Endocrinol. https:// doi.org/10.1155/2017/4795076

10. Chang SW, Ke HL, Tsai CW, Lien CS, Liao WL, Lin HH, Lee MH, Wu HC, Chang CH, Chen CC, Lee HZ, Bau DT (2012) The role of XRCC6 T-991C functional polymorphism in renal cell carcinoma. Anticancer Res. 32:38553860

11. Hsu CM, Yang MD, Chang WS, Jeng LB, Lee MH, Lu MC, Chang SC, Tsai CW, Tsai Y, Tsai FJ, Bau DT (2013) The contribution of XRCC6/Ku70 to hepatocellular carcinoma in Taiwan. Anticancer Res. 33:529-535

12. Jia J, Ren J, Yan D, Xiao L, Sun R (2015) Association between the XRCC6 polymorphisms and cancer risks: a systematic review and meta-analysis. Medicine. 94:283-298

13. Hsia TC, Liu CJ, Chu CC, Hang LW, Chang WS, Tsai CW, Wu C, Lien CS, Liao WL, Ho CY, Bau DT (2012) Association of DNA double-strand break gene XRCC6 genotypes and lung cancer in Taiwan. Anticancer Res. 32:1015-1020

14. Jarow JP (2001) Effects of varicocele on male fertility. Hum Reprod Update. 7:59-64
15. Gorelick Jl, Goldstein M (1993) Loss of fertility in men with varicocele. Fertil Steril. 59:613-616

16. Lewis S, Aitken R (2005) DNA damage to spermatozoa has impacts on fertilization and pregnancy. Cell and Tissue Res. 322:33-41

17. Cohen-Bacrie P, Belloc S, Ménézo YJ, Clement $P$, Hamidi J, Benkhalifa M (2009) Correlation between DNA damage and sperm parameters: a prospective study of 1,633 patients. Fertil Steril. 91:1801-1805

18. Agarwal A, Said TM (2003) Role of sperm chromatin abnormalities and DNA damage in male infertility. Hum Reprod Update. 9:331-345

19. Ouimet $M$, Cassart $P$, Larivière $M$, Kritikou EA, Simard J, Sinnett D (2012) Functional analysis of promoter variants in KU70 and their role in cancer susceptibility. Genes Chrom Cancer. 51(11):1007-1013

20. Wang W, Pan X, Huo X (2012) A functional polymorphism C-1310G in the promoter region of Ku70/XRCC6 is associated with risk of renal cell carcinoma. Mol Carcin. 51:E183-E190

21. Khanna KK, Jackson SP (2001) DNA double-strand breaks: signaling, repair and the cancer connection. Nat Genet. 27:247-254

22. Bau DT, Mau YC, Ding SL, Wu PE, Shen CY (2007) DNA doublestrand break repair capacity and risk of breast cancer. Carcinogenesis. 28:1726-1730

23. Bau DT, Fu YP, Chen ST, Cheng TC, Yu JC, Wu PE, Shen CY (2004) Breast cancer risk and the DNA double-strand break endjoining capacity of nonhomologous end-joining genes are affected by BRCA1. Cancer Res. 64: 5013-5019

\section{Publisher's Note}

Springer Nature remains neutral with regard to jurisdictional claims in published maps and institutional affiliations.

\section{Submit your manuscript to a SpringerOpen ${ }^{\circ}$ journal and benefit from:}

- Convenient online submission

- Rigorous peer review

- Open access: articles freely available online

- High visibility within the field

- Retaining the copyright to your article

Submit your next manuscript at $\boldsymbol{\nabla}$ springeropen.com 